\title{
Trace Element Concentrations in Hydrothermal Silica Deposits as a Potential Biosignature
}

\author{
Andrew Gangidine, ${ }^{1}$ Jeff R. Havig, ${ }^{2}$ David A. Fike, ${ }^{3}$ Clive Jones, ${ }^{3}$ Trinity L. Hamilton, ${ }^{4}$ and Andrew D. Czaja ${ }^{1}$
}

\begin{abstract}
Uncovering and understanding the chemical and fossil record of ancient life is crucial to understanding how life arose, evolved, and distributed itself across Earth. Potential signs of ancient life, however, are often challenging to establish as definitively biological and require multiple lines of evidence. Hydrothermal silica deposits may preserve some of the most ancient evidence of life on Earth, and such deposits are also suggested to exist on the surface of Mars. Here we use micron-scale elemental mapping by secondary ion mass spectrometry to explore for trace elements that are preferentially sequestered by microbial life and subsequently preserved in hydrothermal deposits. The spatial distributions and concentrations of trace elements associated with life in such hydrothermal silica deposits may have a novel application as a biosignature in constraining ancient life on Earth as well as the search for evidence of past life on Mars. We find that active microbial mats and recent siliceous sinter deposits from an alkaline hot spring in Yellowstone National Park appear to sequester and preserve Ga, $\mathrm{Fe}$, and perhaps $\mathrm{Mn}$ through early diagenesis as indicators of the presence of life during formation. Key Words: Biosignature-Hydrothermal-Trace element-Silica-Mars-Microfossil. Astrobiology 20, 525-536.
\end{abstract}

\section{Introduction}

$\mathbf{I}^{\mathrm{r}}$ DENTIFYING EVIDENCE of ancient life on Earth is a difficult task-life in the Archean consisted of microscopic organisms, and the rocks in which they are preserved have undergone diagenesis and metamorphism over billions of years. Successfully discovering fossilized microbial life in the rock record can shed light on the occurrence and function of early life, though this is often challenging. Organic matter is frequently poorly preserved over geologic time, and microbial morphologies are relatively simple, sharing similarities with structures of nonbiological origins (e.g., Muscente et al., 2018). Thus, it is crucial to have multiple complementary biosignatures (substances/phenomena providing evidence of life) to provide unequivocal evidence of life. The applications of such research also extend beyond Earth through projects such as the European Space Agency's ExoMars mission and NASA's Mars Science Laboratory and Mars 2020 missions, the latter of which will soon search for evidence of life on Mars and collect samples to be returned to Earth for additional analyses. The search for past life on extraterrestrial bodies will require very strong evidence of biogenicity, and selection of the best possible samples to return to Earth requires our best initial detection efforts.
One common factor shared by well-preserved putative microfossils in the rock record is that they are encased in microcrystalline silica (i.e., chert), which has an extraordinarily high preservation potential (e.g., Walter et al., 1998; Schopf et al., 2007). Terrestrial hot springs, such as those found in Yellowstone National Park, are modern examples of often silica-saturated water and exhibit high preservation potential through the silicification of microbes. Hot spring water can rapidly precipitate mineral deposits (e.g., siliceous sinter), which can trap microorganisms and cause fossilization via the encrustation of cell walls and/or sheaths (Cady and Farmer, 1996; Konhauser et al., 2003). Recent data from the Mars Reconnaissance Orbiter's High Resolution Imaging Science Experiment (HiRISE), Context Camera (CTX), and Compact Reconnaissance Imaging Spectrometer for Mars (CRISM), as well as the Mars Exploration Rover (MER) Spirit, have shown that silica deposits of potential hydrothermal origin are also present across the surface of Mars (e.g., Squyres et al., 2008; Arvidson et al., 2010; Rice et al., 2010; Skok et al., 2010; Schwenzer et al., 2012; Wray, 2013; Ruff and Farmer, 2016).

Here we report a micron-scale, spatially resolved potential biosignature of sequestered and preserved trace elements relative to silicified microorganisms in hydrothermal sinter

\footnotetext{
${ }^{1}$ Department of Geology, University of Cincinnati, Cincinnati, Ohio.

${ }^{2}$ Department of Earth and Environmental Sciences, University of Minnesota, Minneapolis, Minnesota.

${ }^{3}$ Department of Earth and Planetary Sciences, Washington University in St. Louis, Saint Louis, Missouri.

${ }^{4}$ Department of Plant and Microbial Biology and the Biotechnology Institute, University of Minnesota, St. Paul, Minnesota.
} 
deposits. This biosignature could provide an additional tool to enhance current methods for determining biogenicity in conjunction with providing information on paleoenvironmental conditions.

\section{Materials and Methods}

Samples of siliceous sinter (amorphous silica precipitated from mineral water) used in this study were collected from a $\sim 6 \mathrm{~m}$ tall deposit (Steep Cone) within the Sentinel Meadows of the Lower Geyser Basin in the northwest portion of the Yellowstone Caldera (Figs. 1 and 2a). The Yellowstone Plateau became free of ice following the Pinedale glaciation

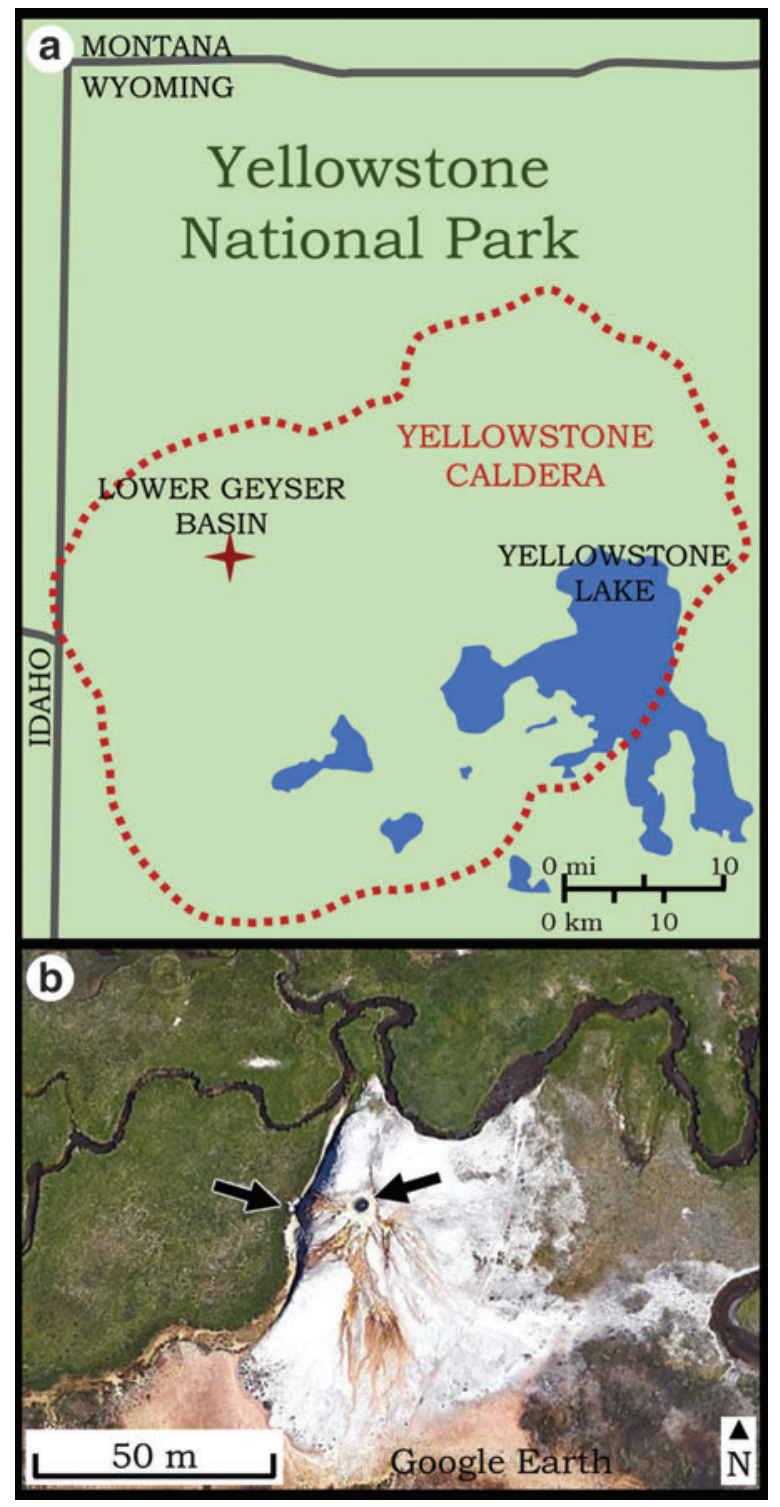

FIG. 1. (a) Map of Yellowstone National Park, showing the Yellowstone Caldera boundary and the location of Lower Geyser Basin, the location of Steep Cone hot spring (44.566635 latitude, -110.863223 longitude). (b) Satellite image of Steep Cone hot spring as well as the stream that crosses Sentinel Meadow and leads to the exposure of its stratigraphy. Arrows in (b) indicate the cut face of the spring imaged in Fig. 2a and the hot spring source in Fig. $2 b$.
13,000-14,000 years ago (Pierce, 2003), and Steep Cone formed as hydrothermal water containing silica overflowed from the hot spring, resulting in sinter precipitation. The source water of Steep Cone $\left(\mathrm{pH} 7.6,93^{\circ} \mathrm{C}\right.$, as measured in 2017; see Table 1) actively precipitates siliceous sinter on the surface of the deposit (Fig. 2b). Source water was measured for $\mathrm{pH}$, temperature, and conductivity and sampled and analyzed for aqueous geochemistry by using techniques previously described (Havig et al., 2015; Schuler et al., 2017; Havig and Hamilton, 2019).

Eleven samples were collected from Steep Cone, both at the surface of the structure and also from layers of strata exposed along the side of Steep Cone via a stream cut. These samples span a timeline of the depositional history of the hot spring and the life associated with it. The discharge channels of Steep Cone $\left(<70^{\circ} \mathrm{C}\right)$ contain Gram-negative, likely photosynthetic bacterial filaments within mucilaginous sheaths (Fig. 2c, 2d). The filaments are further embedded within extracellular polymeric substance (EPS) which can be preserved in the rock record when silicified (Handley et al., 2008; Smythe et al., 2016). Recently deposited sinter near the top of Steep Cone displays orange pigment similar to what is seen in photosynthetic mats in the discharge channels and preserves filamentous microorganisms that have become encased in the precipitated silica sinter (Fig. 2e). Sinter from the exposed strata near the base of Steep Cone contain the fossilized remains of filaments with the same size and morphology as those from the top of Steep Cone (Fig. 2f), but they are devoid of pigment. Microbial mats present in Steep Cone's discharge channels also contain similarly orange-pigmented, albeit narrower, filaments within EPS (Fig. 2g), while similar microbial mat textures are found at the base of Steep Cone (Fig. 2h).

Five types of samples from Steep Cone were chosen for analyses: recently silicified filaments from just beneath an active discharge channel, older silicified filaments within a microbial mat texture from the middle strata, silicified filaments within a microbial mat texture from the oldest available base strata, modern mats from an active discharge channel, and silicified mats from the base of the deposit (see Fig. 2 for details). Living filaments from the discharge channel of Steep Cone (yellow arrow, Fig. 2a) have silica coatings that surround the carbonaceous mucilaginous sheaths of the microbial filaments (Fig. 3a-3b, 3g-3h). Siliceous sinters from Steep Cone showed preservation of silica coatings throughout the strata (Fig. 3c-3f).

Filaments and mats collected from Steep Cone's main discharge channel were imaged via white light microscopy using an Olympus BX-41 microscope (UPlanFl $10 \times$ and $20 \times$, having numerical apertures of 0.30 and 0.50 , respectively) and an Olympus SC30 digital camera and by scanning electron microscopy (SEM). The elemental composition of the filaments was determined by energy dispersive X-ray spectroscopy. These analyses were performed with a SCIOS dual-beam scanning electron microscope in the Advanced Materials Characterization Center at the University of Cincinnati. Analyses were performed under high vacuum using a $\mathrm{Pt} / \mathrm{Au}$ coating and a voltage of $5 \mathrm{kV}$ at $7 \mathrm{~mm}$ working distance. White light and electron micrography provided context images and were used to select areas of interest (i.e., microbial mat textures and filaments exposed at the surface of prepared thin sections) for subsequent secondary ion mass spectrometry 


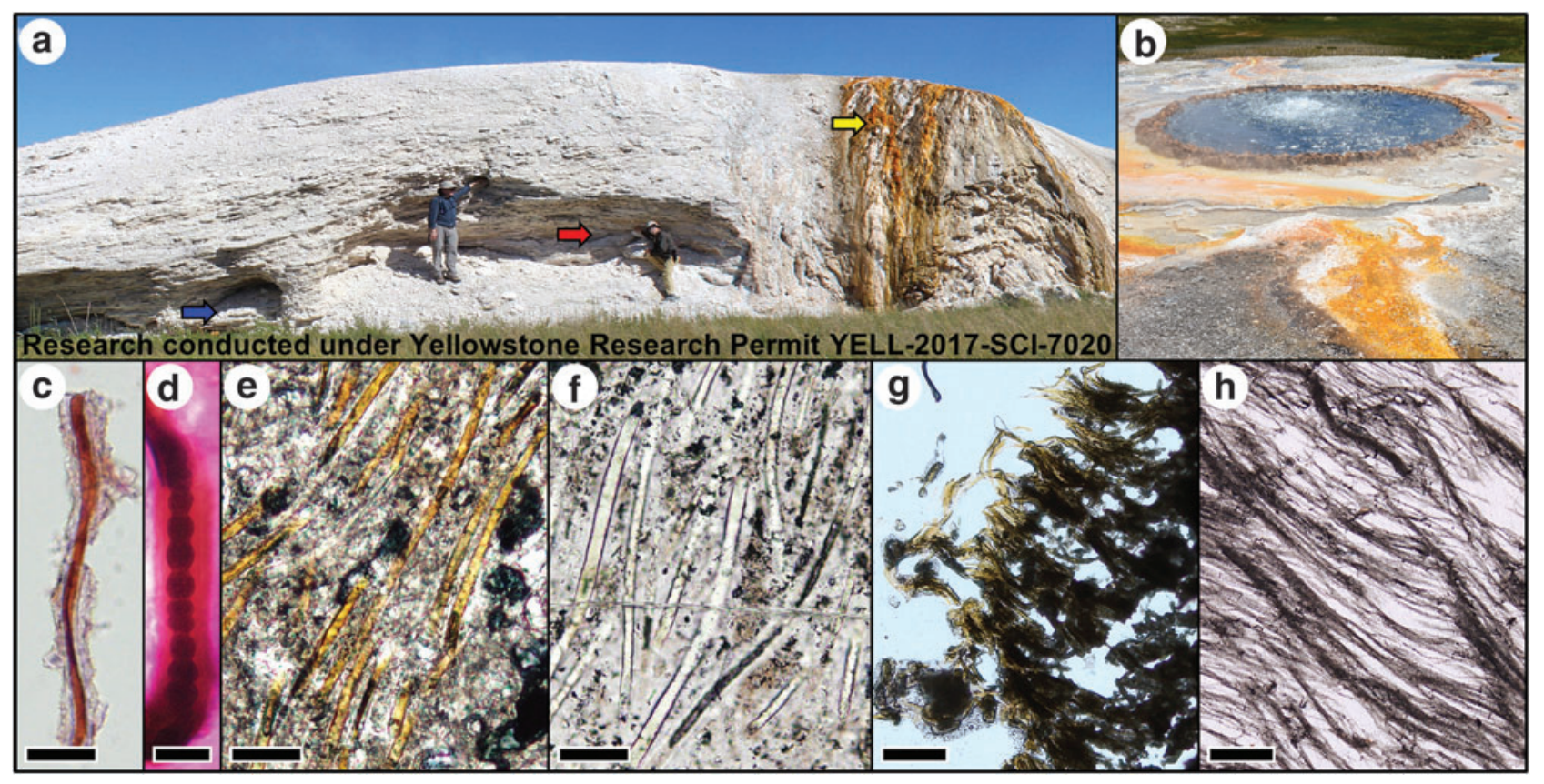

FIG. 2. Steep Cone, Lower Geyser Basin, Yellowstone National Park, USA. (a) Layers of exposed strata and a modern spring discharge channel. (b) Hot spring located on the top of Steep Cone. The orange pigment in the discharge channels indicates the presence of photosynthetic microorganisms. (c) and (d) Photomicrographs of a Gram-negative filament illustrating a mucilaginous coating (panel c, scale bar $=20 \mu \mathrm{m}$ ) and cellular trichome (panel $\mathrm{d}$, scale bar $=5 \mu \mathrm{m}$ ) collected from the discharge channel of Steep Cone (near the yellow arrow in panel a). Preserved microbial filaments are found throughout the deposit including in sinter (e) near the top of Steep Cone (yellow arrow in panel a) displaying orange pigment, and in (f) the lower strata of Steep Cone devoid of pigment (red arrow in panel a). Scale bars in (e) and (f) $=20 \mu \mathrm{m}$. Similarly, densely packed smaller filaments in microbial mats are found (g) near the top of Steep Cone (in a discharge channel, near the yellow arrow in panel a), and similar morphologies are preserved in sinter (h) at the base of the deposit (blue arrow in panel a). Scale bars in $(\mathrm{g})$ and $(\mathrm{h})=200 \mu \mathrm{m}$.

(SIMS) analyses (see below). Thin sections were prepared for SIMS measurements by mounting samples on 1 " round slides, polishing to a $2 \mu \mathrm{m}$ (peak to valley) smoothness, and coating with $\mathrm{Au}$ (to alleviate sample charging).

Eleven samples from Steep Cone, spanning from modern microbial mats to the most ancient layers accessible, were chosen for elemental mapping by SIMS by use of a Cameca IMS 7f-GEO system at Washington University in St. Louis. Within each of these samples, one or more 100 by $100 \mu \mathrm{m}$

Table 1. Steep Cone Hot Spring Geochemistry Data Collected From the Source in June 2017

\begin{tabular}{lc}
\hline Parameter & Value \\
\hline $\mathrm{pH}$ & 7.645 \\
$\mathrm{mV}$ & -38.4 \\
$\mathrm{Temperature}$ & $92.7^{\circ} \mathrm{C}$ \\
$\mathrm{Conductivity}$ & $1457 \mu \mathrm{S} / \mathrm{cm}$ \\
$\mathrm{SiO}_{2}$ & $4.76 \mathrm{mmol} / \mathrm{L}$ \\
$\mathrm{Cr}$ & $26.06 \mathrm{nmol} / \mathrm{L}$ \\
$\mathrm{Mn}$ & $14.73 \mathrm{nmol} / \mathrm{L}$ \\
$\mathrm{Fe}$ & $270.92 \mathrm{nmol} / \mathrm{L}$ \\
$\mathrm{Ga}$ & $236.51 \mathrm{nmol} / \mathrm{L}$
\end{tabular}

Collection and analyses conducted as described previously (Havig et al., 2015; Schuler et al., 2017; Havig and Hamilton, 2019). Trace element analyses were determined via ICP-MS at the Analytical Geochemistry Laboratory in the Department of Earth and Environmental Sciences at the University of Minnesota. Dissolved silica $\left(\mathrm{SiO}_{2}\right)$ was determined via DR 1900 spectrophotometer (Hach Company, Loveland, $\mathrm{CO}$ ). areas of interest were targeted for major $(\mathrm{C}, \mathrm{N}, \mathrm{Si}, \mathrm{P}$, and $\mathrm{S})$ and trace ( $\mathrm{Al}, \mathrm{Cr}, \mathrm{Mn}, \mathrm{Fe}$, and $\mathrm{Ga}$ ) element analyses to quantify the concentrations and spatial distributions of these elements relative to modern and silicified microbial mats or filaments from Steep Cone. The trace elements chosen for analyses were selected based on previous work that showed the enrichment of trace elements including $\mathrm{Al}, \mathrm{Cr}, \mathrm{Mn}, \mathrm{Fe}$, and $\mathrm{Ga}$ in Yellowstone hot spring communities (Havig, 2009). Major and trace elements were measured as negative ions (produced by $\mathrm{Cs}^{+}$primary ion bombardment) and positive ions (produced by $\mathrm{O}^{-}$primary ion bombardment), respectively, in order to provide optimum sensitivity. Silicon was also included with each positive secondary ion image of trace elements in order to facilitate positive and negative ion image co-registration. Because SIMS instruments do not form a negative ion of nitrogen and are relatively poor at forming a positive ion, $\mathrm{N}$ was monitored as $\mathrm{CN}^{-}$, which provided an ion map of nitrogen in carbon-rich locations. The primary beam current and net impact energy was $25 \mathrm{pA}$ $(20 \mathrm{keV})$ and $140 \mathrm{pA}(23 \mathrm{keV})$ for $\mathrm{Cs}^{+}$and $\mathrm{O}^{-}$, respectively, and the beam diameter was $1-2 \mu \mathrm{m}$ in each case.

Careful attention was paid to interference considerations. The mass resolving power (MRP) required to separate ${ }^{12} \mathrm{C}^{14} \mathrm{~N}^{-}$from ${ }^{13} \mathrm{C}_{2}^{-}$is 7,152 and from ${ }^{24} \mathrm{MgH}_{2}^{-}$is 10,931 . MRP $>10,000$ is achievable with a $7 \mathrm{f}-\mathrm{GEO}$, but this considerably restricts secondary ion transmission and raises the detection limit for an image of given integration time. Nitrogen was therefore monitored as ${ }^{12} \mathrm{C}^{15} \mathrm{~N}^{-}$(noting that nitrogen maps may only be interpreted in $\mathrm{C}$-rich locations), 


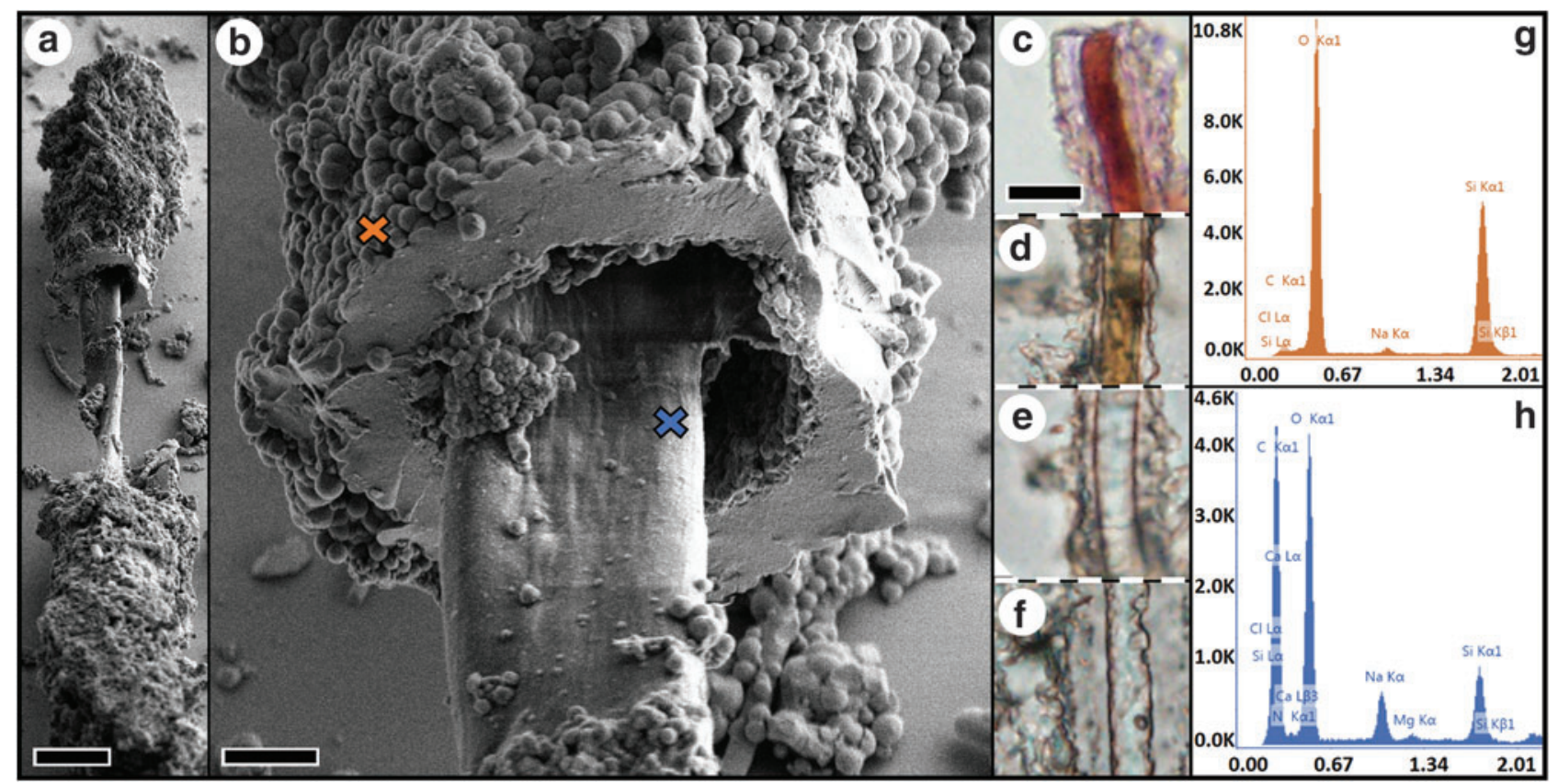

FIG. 3. Filaments from Steep Cone, displaying a coating of silica. (a) Scanning electron microscope image of a recently living filament collected from a Steep Cone discharge channel (yellow arrow, Fig. 2a) showing the silica coating surrounding the filament. Scale bar $=10 \mu \mathrm{m}$. (b) High-magnification view of the silica coating surrounding the filament, showing characteristic botryoidal texture. Scale bar $=2 \mu \mathrm{m}$. Orange and blue X marks indicate location of point analyses of a silica coating and filament, respectively, by energy dispersive X-ray spectroscopy shown in (g) and (h). (c-f) A series of photomicrographs of progressively older filaments (i.e., from progressively deeper within the Steep Cone stratigraphy) displaying increasing levels of organic alteration but preservation of the silica coating. (c) A living filament collected from an active discharge channel of Steep Cone ( $c f$. filament illustrated in panels a and b) subjected to a Gram stain highlighting biomass in red. Scale bar $=10 \mu \mathrm{m}$ and applies to (c-f). (d) A recently silicified filament collected from the top of Steep Cone (yellow arrow, Fig. 2a) shows pigment retained within the silica coating. (e) A silicified filament located deeper within the sample taken from the top of Steep Cone (yellow arrow, Fig. 2a) shows a loss of pigment but retention of the filamentous morphology and silica coating after several years of diagenesis. (f) A silicified filament from sinter collected from halfway through the $\sim 14 \mathrm{ka}$ deposit (red arrow, Fig. 2a), showing retention of the filamentous morphology and silica coating. (g) Silica spectrum from the spot marked with an orange $X$ in (b). (h) Spectrum from the spot marked with a blue $X$ in (b), showing the presence of organic $\mathrm{C}$, and smaller amounts of $\mathrm{Na}$ and $\mathrm{Cl}$.

and all negative secondary ion images were acquired with an MRP of 4500 , sufficient to separate $\mathrm{P}^{-}$from ${ }^{30} \mathrm{SiH}^{-}$and ${ }^{32} \mathrm{~S}^{-}$from ${ }^{16} \mathrm{O}_{2}^{-}$. The positive secondary ion images were acquired by using an MRP of 6000. This was sufficient to resolve ${ }^{27} \mathrm{Al}^{+}$from ${ }^{12} \mathrm{C}^{15} \mathrm{~N}^{+},{ }^{28} \mathrm{Si}^{+}$from $\mathrm{AlH}^{+},{ }^{52} \mathrm{Cr}^{+}$from ${ }^{28} \mathrm{Si}^{24} \mathrm{Mg}^{+}, \mathrm{Mn}^{+}$from ${ }^{54} \mathrm{FeH}^{+}$and ${ }^{28} \mathrm{SiAl}^{+},{ }^{56} \mathrm{Fe}^{+}$from ${ }^{28} \mathrm{Si}_{2}{ }^{+}$ and $\mathrm{MnH}^{+}$, and ${ }^{69} \mathrm{Ga}^{+}$from ${ }^{28} \mathrm{Si}^{29} \mathrm{Si}^{12} \mathrm{C}^{+}$, and ${ }^{40} \mathrm{Ca}^{29} \mathrm{Si}^{+}$. It was not sufficient to completely separate Mn from ${ }^{54} \mathrm{CrH}^{+}$ (6300); however, the magnet calibration for Mn was offset from the center of the peak, away from the potential interference, minimizing the contribution. Nor was it sufficient to separate ${ }^{69} \mathrm{Ga}^{+}$from ${ }^{56} \mathrm{Fe}^{13} \mathrm{C}^{+}$; however, the contribution of the latter interference was minimal, as evidenced by regions of relatively high $\mathrm{C}$ and $\mathrm{Fe}$ co-registered count rates showing no correlation with ${ }^{69} \mathrm{Ga}^{+}$count rates.

To quantify and compare the concentrations of trace elements in and around the preserved filaments and mats in the 11 samples studied, averages of the elemental concentrations from regions of interest (ROIs) for each SIMS map were calculated. Below is a description of the method (and see the Supplementary Materials for further explanation; Supplementary Materials are available online at www .liebertonline.com/ast). For filaments, each ROI was a portion of the filament that intersected the surface of the sample and the silica immediately surrounding it, the latter corresponding to the observed silica coatings described above. For each ROI, the average concentrations of trace elements inside the filament and in the silica coating were calculated. For microbial mats, the trace element concentrations were calculated for the entire mat. For the microbial filament samples, background concentrations for each element were also calculated, with the background being defined as areas in the $\mathrm{SiO}_{2}$ matrix not associated with silicified microbial filaments or unidentified organic matter. For the microbial mats, there was no background measurement because the entire sample consisted of microbially associated $\mathrm{SiO}_{2}$. To calculate each average, a minimum of ten 30-by-30 pixel areas (pixel size $=\sim 0.2 \mu \mathrm{m}$, area $=\sim 36 \mu \mathrm{m}^{2}$ ) were selected within the ROIs on each SIMS map. The obtained concentrations for the $\geq 10$ subsampled areas were then used to calculate an average concentration of each trace element of interest. Some analyzed sample areas contained multiple microbial filaments and thus multiple ROIs.

Quantification of the trace element data was achieved by analyzing NIST standard reference materials 610 and 617 (glass reference materials containing known amounts of trace elements). For the elements analyzed, the 95\% confidence level in the documented relative concentration value 
of the reference materials did not exceed $10 \%$. For example, a concentration of $10 \mathrm{mg} / \mathrm{kg}$ would be known within $\pm 1 \mathrm{mg} /$ $\mathrm{kg}$, or better. The NIST reference materials were analyzed by using identical analytical parameters as those used for the unknowns. These data were then used to calculate a sensitivity factor for each element, which was then applied to the raw sample data to provide quantification (see the Supplementary Materials for calculations).

Instrumental detection limits were established for silica trace element measurements by analysis of float zone silicon, using identical analytical parameters as those used for the unknowns. Although float zone silicon is not silica, the continuous implantation of $\mathrm{O}^{-}$by the primary beam provides a moving region of stoichiometry, as the sample is sputtered, similar, though not identical, to silica. Nevertheless, because float zone silicon is an ultrapure form of silicon (industry standard in the semiconductor industry), these measurements of detection limit should be close to those that would be obtained from a putative "ultrapure" silicon dioxide. The detection limits thus obtained were $7,<1,<1,16$, and $<1 \mathrm{mg} / \mathrm{kg}$ for $\mathrm{Al}, \mathrm{Cr}, \mathrm{Mn}, \mathrm{Fe}$, and $\mathrm{Ga}$, respectively. Note that these will strictly apply to the image regions that are predominantly $\mathrm{SiO}_{2}$.

Other analytical techniques were used to characterize the hot spring materials. Raman spectroscopic analyses of the carbonaceous components of the sinter samples (microbial filaments and embedding epoxy) were performed by using a Horiba T64000 Raman microscope. Spectra were acquired with a $50 \times$ long working distance objective $(\mathrm{NA}=0.50)$ and the $514 \mathrm{~nm}$ laser line of a Coherent Innova 90C Ar+ laser with a spot size of $\sim 1 \mu \mathrm{m}$. Data were collected and processed with the software LabSpec (v.5; Horiba, Inc., Edison, NJ). Two sinter samples (from the top and base of Steep Cone, respectively) were analyzed by using X-ray diffraction (XRD) in order to assess the dominant phase of silica present in each sample to determine if there was a measurable difference in diagenetic alteration corresponding with age (depth within the deposit). XRD analyses were performed with a Siemens D-5000 powder diffractometer.

\section{Results}

For the 11 different samples from five depositional locations within the strata of Steep Cone, major and trace element SIMS maps document apparent biologically specific trends of elemental concentrations in both live and silicified microbial mats and microbial filaments (e.g., Fig. 4). Distinct, elevated concentrations of $\mathrm{Ga}, \mathrm{Fe}$, and $\mathrm{Mn}$ (ranked in order from most to least robust evidence of sequestration) were found to be spatially associated with silicified microbial filaments, either colocalized with the $\mathrm{C}$ signal of the filaments or in the silica coatings immediately surrounding the filaments (e.g., Fig. 5). Aluminum was not measured in concentrations above the detection limit in any sample. The Ga distribution appears to correspond with the silica coating surrounding each filament (e.g., Fig. 3), which is preserved throughout silicification over the $\sim 14 \mathrm{ka}$ timescale of the samples analyzed from Steep Cone. Trace element sequestrations of $\mathrm{Ga}, \mathrm{Fe}$, and $\mathrm{Mn}$ are also observed in modern microbial mats collected from the active discharge channels of Steep Cone and in silicified microbial mats collected from the base of Steep Cone. Modern mats have EPS that is high in Si content with Mn, Fe, and Ga colocalized, and this signal is preserved in both the modern mats as well as the silicified mats from the base of Steep Cone (Fig. 6). Chromium also appears to be colocalized with the $\mathrm{C}$ map of silicified microbial filaments in three samples, though the relatively low number of counts generated from the SIMS analyses and small sample size does not yield sufficient information to identify a definitive trend (Fig. 7). Additional SIMS elemental maps from multiple analyses of each sample/ sample type (including samples from various locations in Steep Cone's strata, epoxy, and optimal cutting temperature

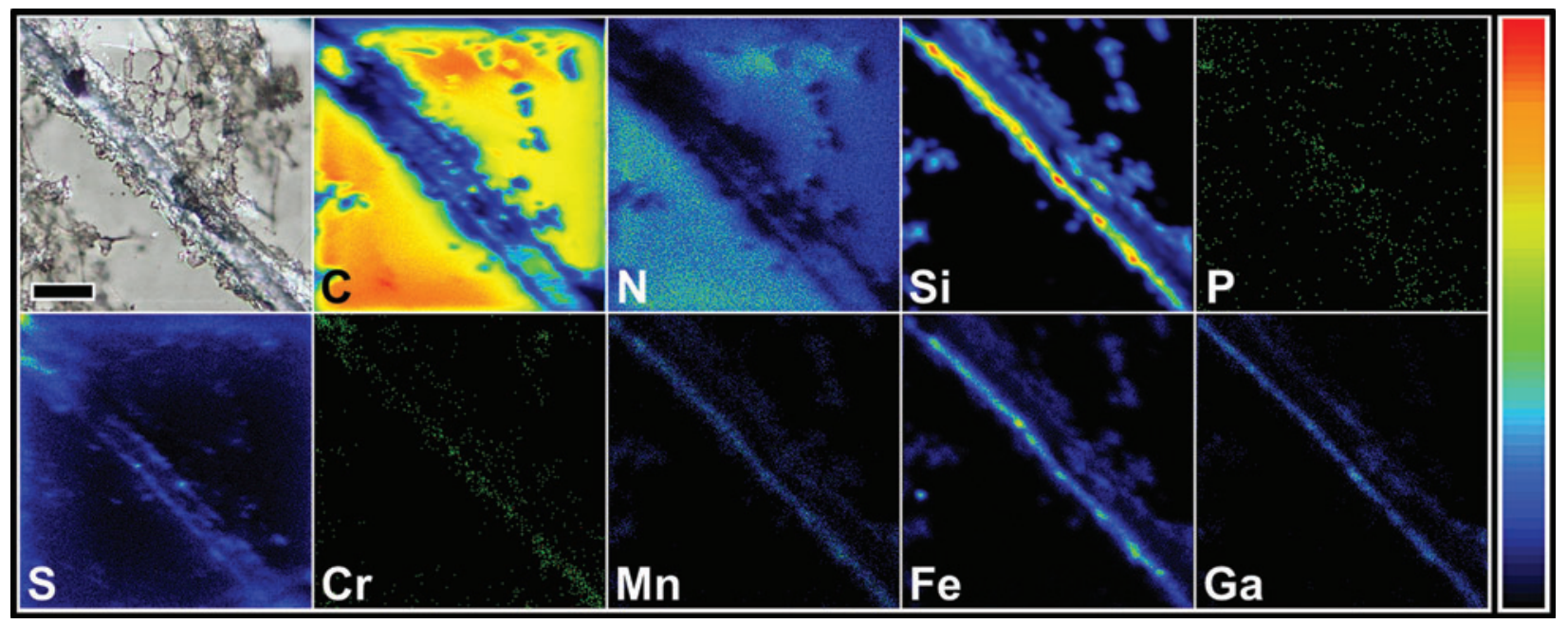

FIG. 4. Secondary ion mass spectrometry (SIMS) analyses showing the distribution of a variety of primary and trace elements in a single silicified microbial filament from the base strata of Steep Cone (near the blue arrow in Fig. 2a). The first panel shows a white light image of a microbial filament bisected at the surface of the thin section (and thus analyzed via SIMS), and subsequent panels show elemental maps for the noted elements. Note the high $\mathrm{C}$ and $\mathrm{N}$ mapped outside of the filament is a result of epoxy filling in outer void space. Scale bar $=20 \mu \mathrm{m}$ and applies to all images. The color bar on the right shows relative values from low (blue) to high (red). $\mathrm{C}=$ carbon, $\mathrm{N}=$ nitrogen, $\mathrm{Si}=$ silicon, $\mathrm{P}=$ phosphorous, $\mathrm{S}=$ sulfur, $\mathrm{Cr}=$ chromium, $\mathrm{Mn}=$ manganese, $\mathrm{Fe}=$ iron, $\mathrm{Ga}=$ gallium . 


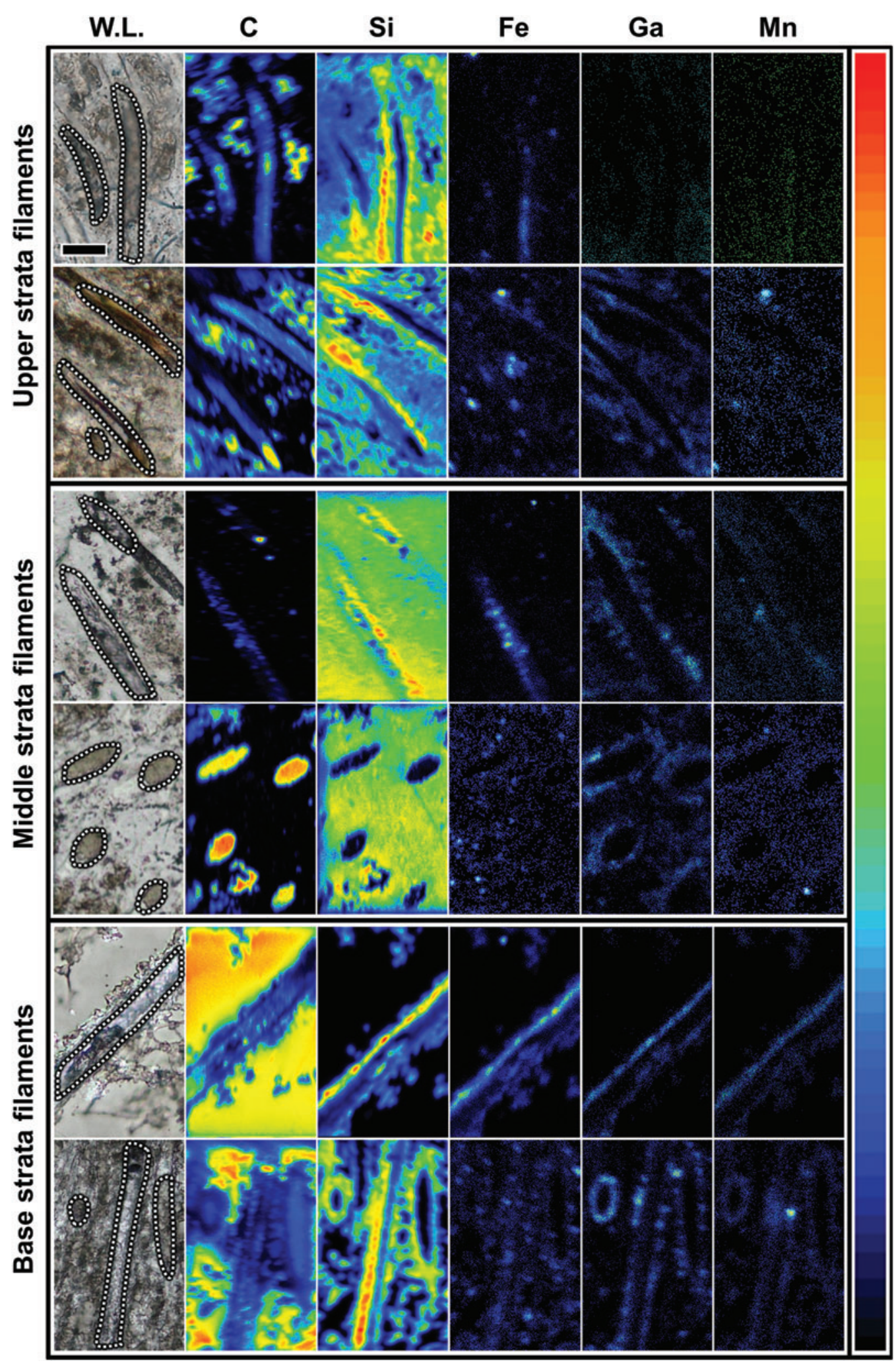

FIG. 5. Secondary ion mass spectrometry analyses of silicified microbial filaments from various levels of strata of Steep Cone. The first panel of each column shows a white light (W.L.) image of the silicified filaments with a white outline surrounding the area of the filament which has been bisected at the surface of the thin section (and thus analyzed via SIMS). Subsequent panels show the elemental maps for the area shown in the first panel for each element noted on the top row. The color bar on the right shows relative values from low (blue) to high (red). Scale bar $=20 \mu \mathrm{m}$ and applies to all images. See Fig. 9 and the Supplementary Materials for quantified concentrations of trace elements and analyses of additional samples. $\mathrm{C}=$ carbon, $\mathrm{Si}=$ silicon, $\mathrm{Fe}=$ iron, $\mathrm{Ga}=$ gallium, $\mathrm{Mn}=$ manganese . 


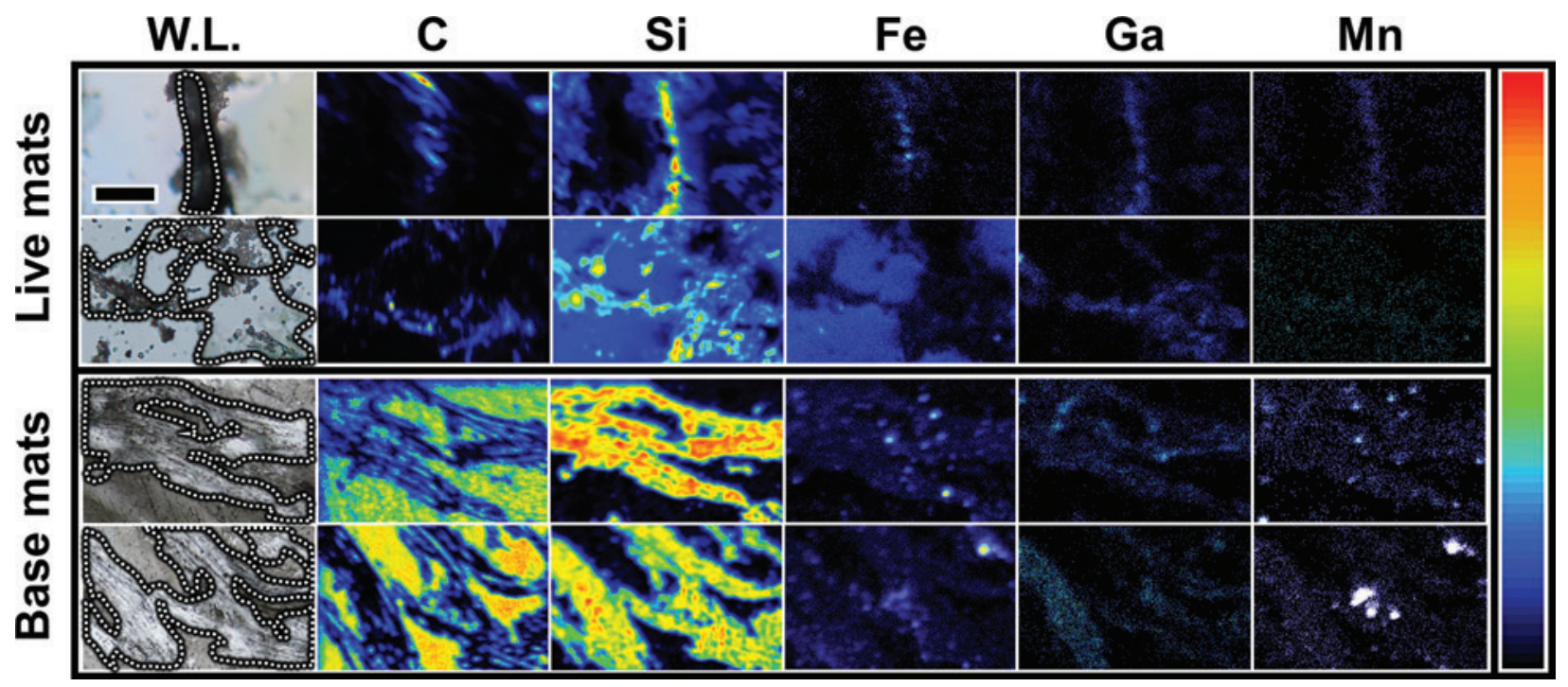

FIG. 6. Secondary ion mass spectrometry analyses of live (at collection) microbial mats from the discharge channel of Steep Cone, and silicified mats from the base of Steep Cone. The first panel of each column shows a white light (W.L.) image of the silicified filaments with a white outline surrounding the area of the mat which has been bisected at the surface of the thin section (and thus analyzed via SIMS). Subsequent panels show the elemental maps for the area shown in the first panel for each element noted on the top row. The color bar on the right shows relative values from low (blue) to high (red). Scale bar $=20 \mu \mathrm{m}$ and applies to all images. See Fig. 9 and the Supplementary Materials for quantified concentrations of trace elements and analyses of additional samples. $\mathrm{C}=$ carbon, $\mathrm{Si}=$ silicon, $\mathrm{Fe}=$ iron, $\mathrm{Ga}=$ gallium, $\mathrm{Mn}=$ manganese .

cryosection media in which modern samples were mounted) can be found in the Supplementary Materials.

Carbon, an essential element in biomass, provided a strong constraint on the location of present or past microbial biomass within the samples analyzed (e.g., Figs. 4-6 and Supplementary Material). Analyses by Raman spectroscopy demonstrated a difference in the molecular-structural composition of the organic material comprising the preserved microbial filaments in the Steep Cone samples and the impregnating epoxy, indicating that the $\mathrm{C}$ signals detected by SIMS are primary and not a result of infilling of voids by epoxy (Fig. 8). Other elements commonly associated with life (N, P, and S) also helped constrain biomass location but were not as consistent as C (likely due to low concentration coupled to poor ionization potential). Iron was found to be enriched (relative to background concentration) in or around preserved microbial filaments from the top, middle, and base strata of Steep Cone (Figs. 5 and 9). In the samples from the top strata of Steep Cone $(n=2)$, five recently silicified microbial filaments were analyzed, all of which showed a higher concentration of iron colocalized with the $\mathrm{C}$ signal of the filament. The same trend was observed in samples from the middle strata of Steep Cone $(n=3)$, where a total of seven silicified microbial filaments were analyzed. In samples from the base strata of Steep Cone $(n=2)$, however, iron instead showed a higher average concentration in the area just outside the silicified filaments. Iron enrichment was also observed in two modern microbial mats and in two silicified microbial mats from the base of Steep Cone (Figs. 6 and 9).

The colocalization of $\mathrm{Ga}$ and $\mathrm{Si}$ was also observed in the two modern microbial mats and two silicified microbial mats from the base of Steep Cone, although the filaments within the modern microbial mats are suspended in a Si-rich EPS, so no individual silica coatings were discerned (Figs. 6 and 9).
Any apparent trend in manganese sequestration was not obvious in the five recently silicified microbial filaments from the upper strata of Steep Cone, but the silicified filaments from the middle and base strata of Steep Cone displayed elevated concentrations of manganese in the area just outside the silicified filaments (e.g., Figs. 5 and 9). Manganese enrichment was also observed in two modern microbial mats and in two silicified microbial mats from the base of Steep Cone (Figs. 6 and 9).

Average values of ROIs analyzed via SIMS (Fig. 9 and Supplementary Material) suggest that elevated $\mathrm{Mn}, \mathrm{Fe}$, and Ga concentrations are associated with microbial filaments and microbial mats during life and are subsequently preserved throughout silicification. Silicified bacterial filaments often show higher concentrations of $\mathrm{Mn}, \mathrm{Fe}$, and $\mathrm{Ga}$ (and perhaps $\mathrm{Cr}$ ) in or around the filaments as compared to background values (e.g., Figs. 5, 7, and 9). Active microbial mats measured were likewise found to have parts-per-millionrange $\mathrm{Mn}, \mathrm{Fe}$, and $\mathrm{Ga}$ concentrations associated with the $\mathrm{SiO}_{2}$ of the mats, and similar concentrations were observed in silicified microbial mats (e.g., Figs. 6 and 9).

$\mathrm{X}$-ray diffraction (XRD) was used to analyze powders prepared from sinter samples from the top and bottom of Steep Cone in order to determine the dominant phase of the silica sinter in each sample. The expected mineralogic diagenesis for silica sinter begins with opal-A and ends with mature quartz, with intermediates including opal-CT and opal-C (e.g., Williams and Crerar, 1985; Lynne et al., 2005). XRD spectra for the topmost and bottommost layer of Steep Cone showed the same major peak position and diffractogram shape, consistent with an XRD pattern for opal-A. There was no apparent shift from the top to bottommost layer of Steep Cone toward an XRD pattern for opal-CT (the next major intermediate step in silica diagenesis) (Fig. 10). 


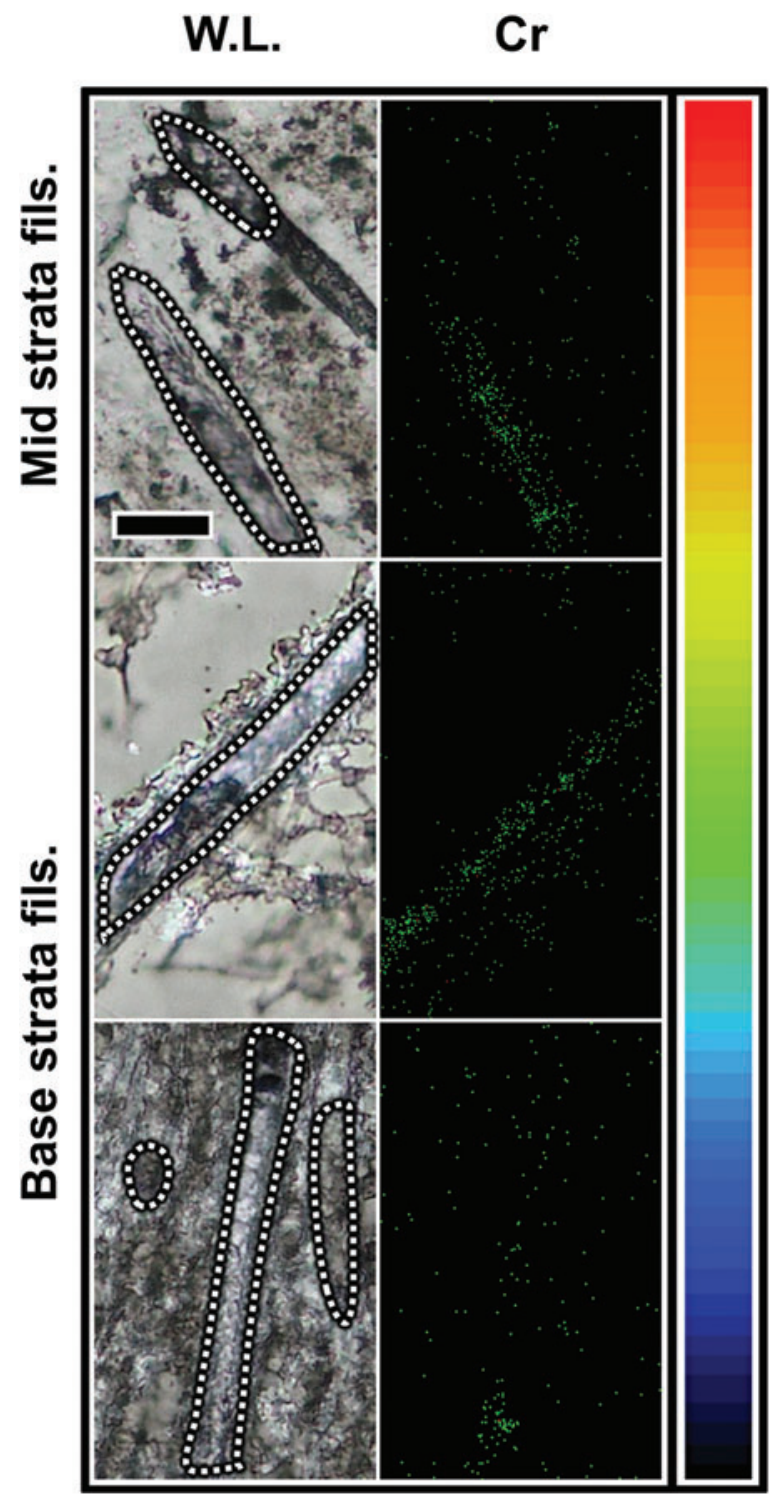

FIG. 7. Secondary ion mass spectrometry analyses of silicified microbial filaments from various levels of strata of Steep Cone which show a potential chromium enrichment. The first panel of each column shows a white light (W.L.) image of the silicified filaments with a white outline surrounding the area of the filament which has been bisected at the surface of the thin section (and thus analyzed via SIMS). The following panels show the elemental maps for chromium $(\mathrm{Cr})$. The color bar on the right shows relative values from low (blue) to high (red). Scale bar $=20 \mu \mathrm{m}$ and applies to all images.

These results confirm that the silica sinter throughout Steep Cone is diagenetically immature and that diagenetic effects are likely not responsible for any variation in trace element sequestration observed in our samples.

\section{Discussion}

We observed sequestration of elements known to be present in Steep Cone's hydrothermal source fluid (see Table 1) in and around microbial filaments and mats present in the discharge channels and sinter of Steep Cone. Microbes can assimilate essential and seemingly non-essential trace elements (espe- cially when similar in charge/size to essential metals), most notably through intracellular accumulation, cell surface interactions, or through adsorption onto extracellular polymeric materials (Johnson, 2006). However, $\mathrm{pH}$ and other abiotic factors affect the solubility of trace elements; and the differences in elemental abundance and distribution depend on a number of processes such as subsurface boiling and resulting phase separation, differential flow paths to the surface, local bedrock composition, and input of allochthonous material (e.g., White et al., 1971; Fournier, 1989; Rye and Truesdell, 1993; Havig, 2009; Nordstrom et al., 2009; Havig et al., 2011; Hurwitz and Lowenstern, 2014). For instance, Cr, Mn, and $\mathrm{Fe}$ are less soluble in alkaline environments (e.g., Ball et al., 2002, 2008, 2010; McCleskey et al., 2005), which may explain the high concentration of these trace elements associated with microbes in sinter from the circumneutral Steep Cone hot spring (Table 1). Below we discuss the observed distributions of trace metals and possible causes along with the potential for these distributions to be a biosignature.

Potential explanations for elevated concentrations of iron and manganese could be attributed to a variety of factors. Various reduced metals (including $\mathrm{Fe}[\mathrm{II}]$ and $\mathrm{Mn}[\mathrm{II}]$ ) can act as energy sources in Yellowstone hot springs (e.g., Shock et al., 2010), although their presence/prevalence throughout hot springs can vary (Spear et al., 2005). Some bacteria sequester Fe under hydrothermal conditions, both for metabolic function and energy via oxidization. Specifically, the acquisition of Fe by microorganisms is imperative in oxygenated, circumneutral $\mathrm{pH}(>6.5)$ environments similar to Steep Cone, where Fe(III) solubility is very low (Konhauser et al., 2011).

Chromium showed apparent sequestration trends in only three samples of silicified filaments and was difficult to characterize due to the low counts generated by the SIMS analyses (Fig. 7). Although $\mathrm{Cr}(\mathrm{VI})$ can be toxic, trace amounts of $\mathrm{Cr}$ are required for enzymatic activity by some microbes (Losi et al., 1994). The speciation of both the hot spring and microbeassociated $\mathrm{Cr}$ is not presently known, so it is uncertain if the presence of $\mathrm{Cr}$ may be linked to chromium detoxification (which has been observed in hot spring dwelling bacteria as a method to reduce the highly toxic and carcinogenic $\mathrm{Cr}(\mathrm{VI})$ to the less toxic, insoluble $\mathrm{Cr}$ (III)) (Cheung and $\mathrm{Gu}, 2007$; Bhowmick et al., 2009) or another phenomenon. The limited number of samples containing $\mathrm{Cr}$ in the present study, however, does not provide sufficient insight into this proposed process.

Elevated gallium concentrations surrounded every silicified filament from the top, middle, and base strata of Steep Cone (Figs. 5 and 9). This location is consistent with the location of the siliceous coating observed immediately surrounding filaments (e.g., Fig. 3). The gallium enrichment in the siliceous filament coating is thus subsequently preserved through at least the $\sim 14$ ka Steep Cone sample.

Hydrothermal fluids can become enriched in $\mathrm{Ga}$ after interacting with underlying rhyolitic bedrock (Smith et al., 2018). When limited by Fe (especially in circumneutral to alkaline $\mathrm{pH}$ environments), bacteria may release $\mathrm{Fe}$ chelating siderophores to scavenge for Fe, which can also complex trivalent metals such as Ga (Johnson, 2006). This could explain the presence of $\mathrm{Ga}$, which, although known to exist in hydrothermal settings, remains poorly characterized (Kuroda, 1940; Smith et al., 2018). Prior work studying photosynthetic microbial mat communities in a nearby hot spring (located within Sentinel Meadows, with a $\mathrm{pH}$ of 7.3) 


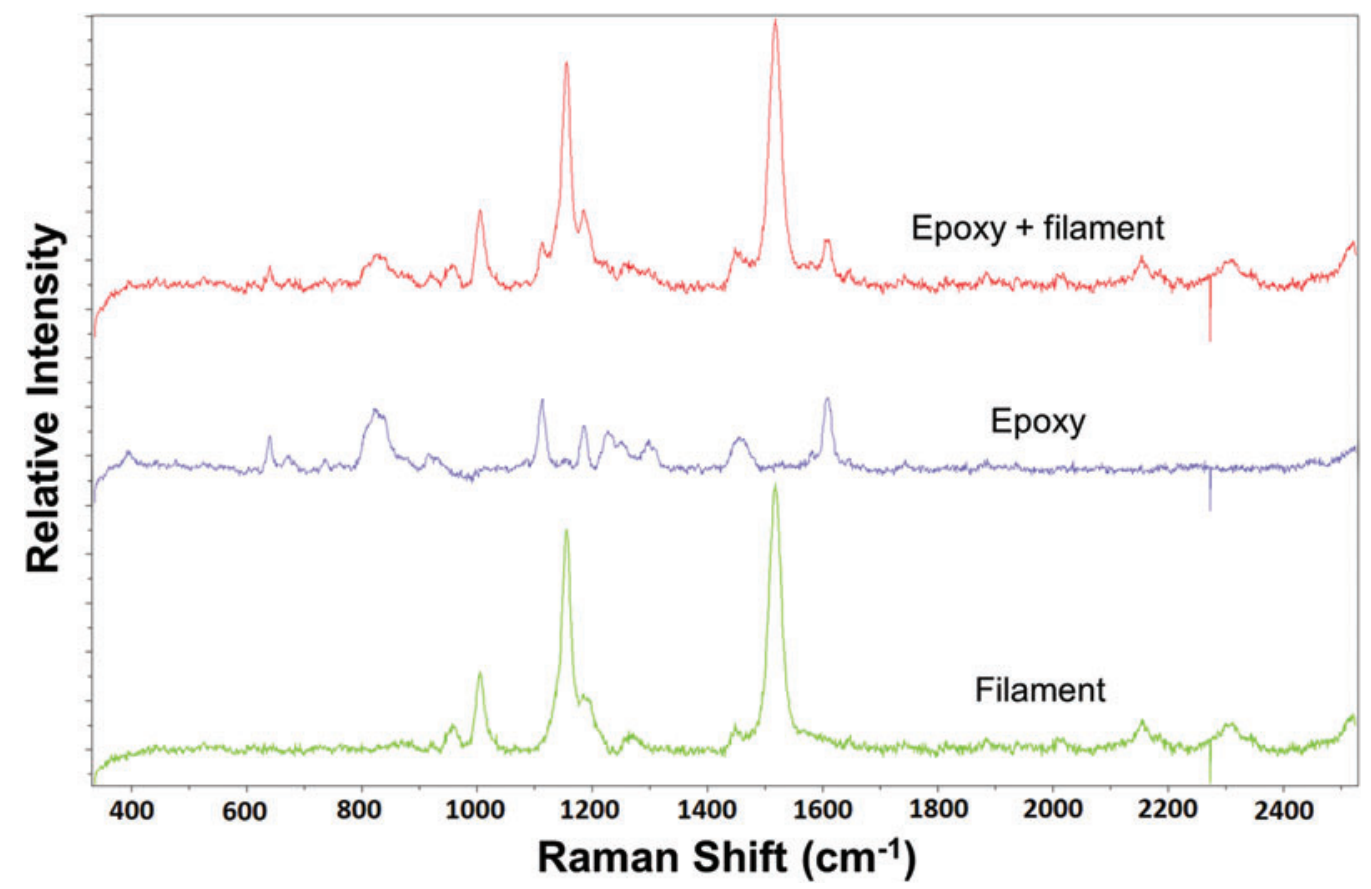

FIG. 8. Raman spectra showing the distinct signals for a Yellowstone microbial filament, mounting epoxy, and a combined spectrum. Spectra have been offset along the $y$-axis for clarity.

has confirmed the production of siderophores by the native mat communities and suggested that both $\mathrm{N}$ and $\mathrm{Fe}$ availability play roles in $\mathrm{Fe}$ transport and siderophore production in such hot spring communities (Thorne, 2012). The systematic recovery of $\mathrm{Ga}$ in microfossils spanning the age of the Steep Cone sinter is consistent with previous work (Havig, 2009) and supports the use of this trace element as a potential biosignature. Thus, the observed presence of $\mathrm{Ga}$ enrichment in silica coatings associated with microbial fil- aments may suggest that, in the rock record, Ga enrichment of siliceous coatings that have colocalized $\mathrm{C}$ (and other primary elements such as $\mathrm{N}$ and $\mathrm{S}$ ) in their interior may provide direct evidence for fossil microbial communities.

The spatially resolved major and trace element concentrations of biologically associated features in hydrothermal sinter appear to survive at least short-term $(\sim 14 \mathrm{ka})$ burial beneath overlying silica layers of the hot spring cone. If these elemental sequestrations persist through diagenesis

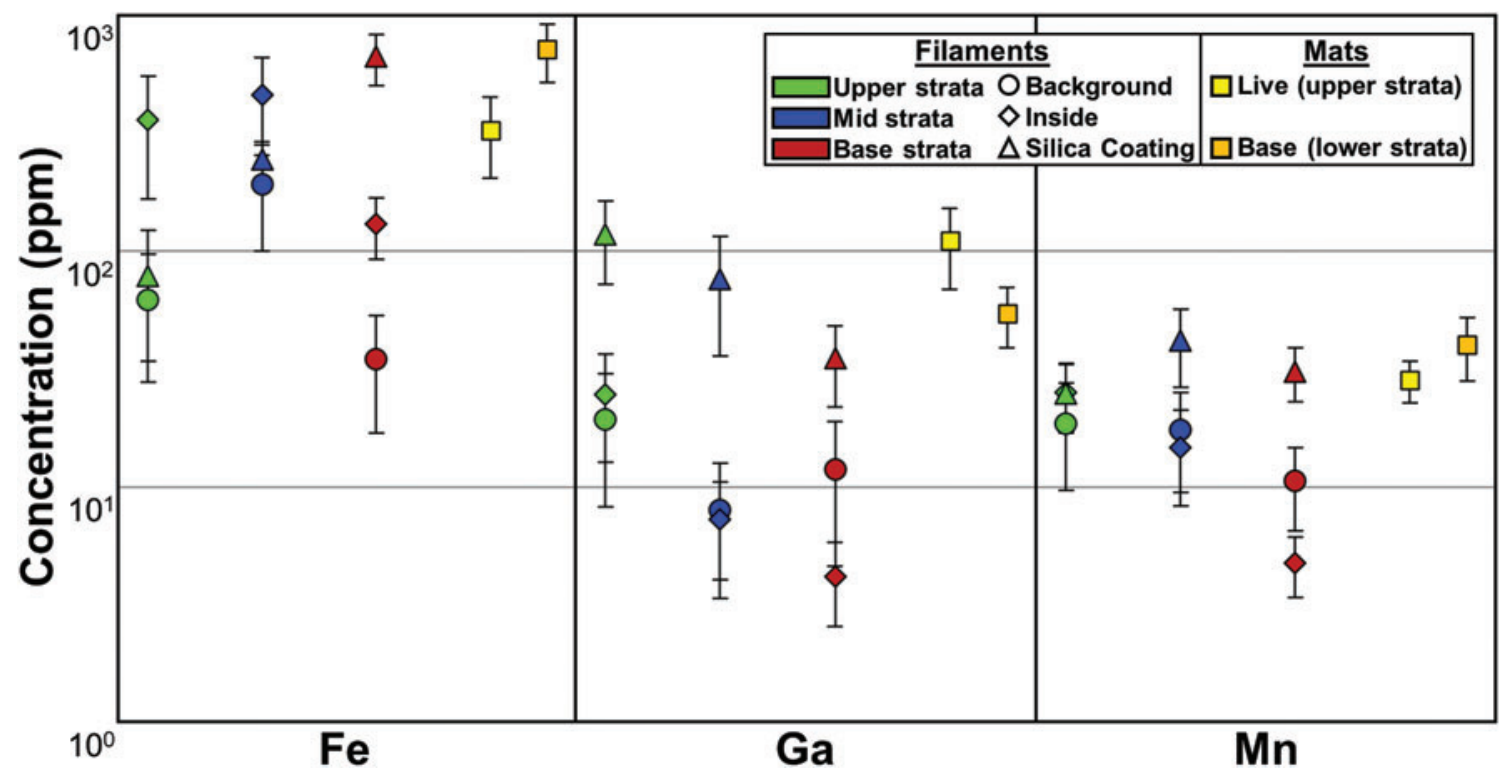

FIG. 9. Average trace element concentrations of microbial filament and microbial mat samples collected from Steep Cone, Yellowstone National Park. Each point represents a combined average of calculated concentrations from multiple $(\geq 10)$ ROIs in each sample group (e.g., the average of all background concentrations for multiple upper strata samples). See the Supplementary Materials for full data and calculations. Error bars represent one standard deviation for the average for each sample group. 


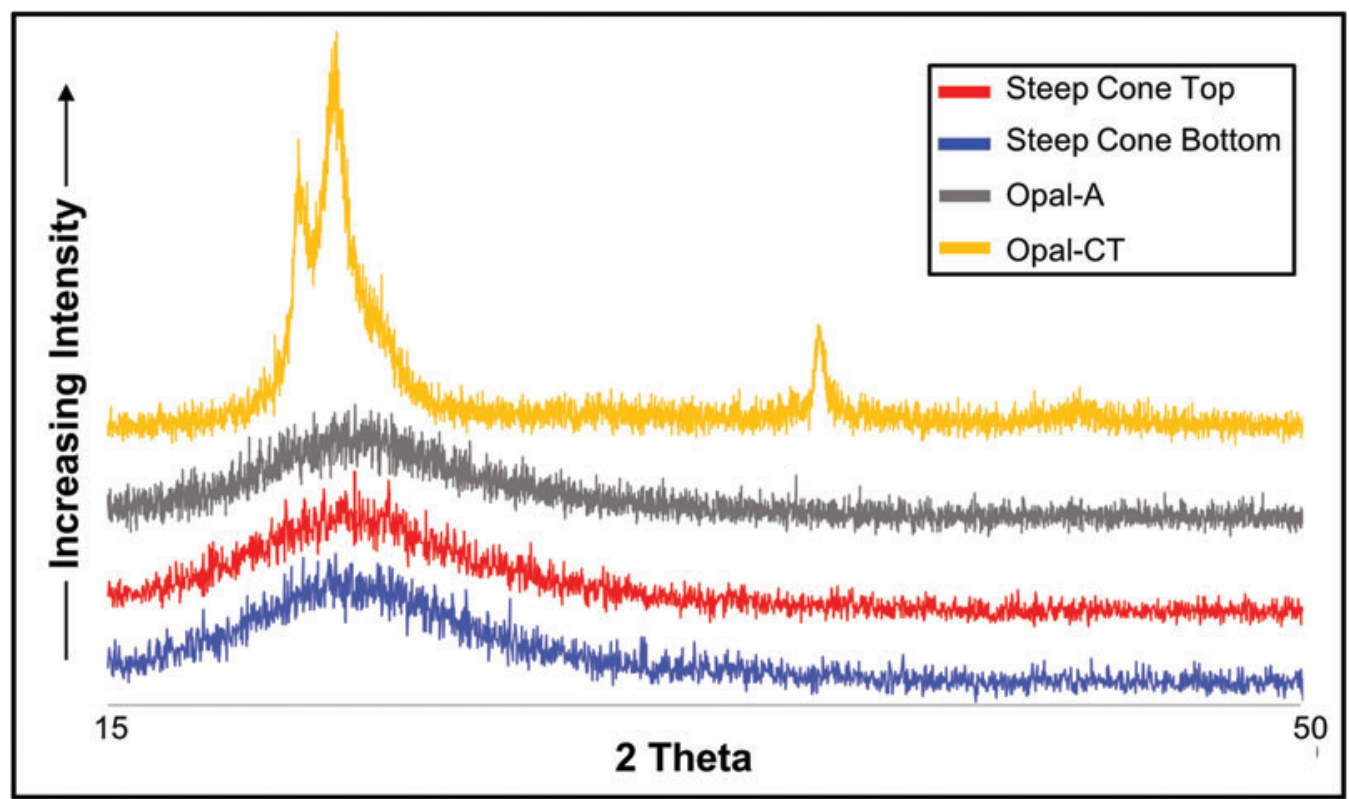

FIG. 10. X-ray diffractograms comparing Opal-CT (from http://rruff.info; RRUFF ID: R060650), amorphous Opal-A (from http://rruff.info; RRUFF ID: R060653), sinter from the topmost layer of Steep Cone, and sinter from the bottommost layer of Steep Cone.

and metamorphism, this method could be applied to ancient hydrothermal samples containing putative microfossils. It is plausible these concentrations and spatial associations may persist in similar amorphous (i.e., diagenetically immature) silica deposits on the surface of Mars, which have been suggested as candidates for preserving evidence of martian microbial life if it ever developed (e.g., Des Marais, 2010; Ruff and Farmer, 2016). This potential biosignature may be useful for future studies constraining ancient life on Earth as well as the search for evidence of past microbial life on Mars. Furthermore, this technique may help guide the selection of samples to be collected and cached at Jezero Crater, the sampling site for the Mars 2020 rover. Specifically, on the crater wall of Jezero, impact-induced hydrothermal deposits could be preserved, including hydrothermal silica deposits (e.g., Abramov and Kring, 2005; Pirajno, 2009; Osinski et al., 2013). Therefore, this study would be directly relevant to potential ancient hot spring samples that may be collected by the Mars 2020 mission and returned by a subsequent sample return mission.

The modern geochemistry of Steep Cone is not unique throughout geothermal springs in Yellowstone National Park, which hosts numerous hot springs with similar geochemistries including the Lower, Midway, and Upper Geyser Basins (e.g., Ball et al., 2002; McCleskey et al., 2005; Ball et al., 2008, 2010). Likewise, all trace elements featured in this study have also been found in hot spring fluids in basaltic-hosted geothermal systems (e.g., Kaasalainen et al., 2015), suggesting the availability of these elements is not limited to hydrothermal systems with underlying rhyolitic bedrock (e.g., Yellowstone). Future studies across a broader treatment of sampling sites may provide insight as to the universality of the sequestrations observed in this study, what variation may exist in geochemically distinct settings, and what other trace elements may have application as potential biosignatures.

\section{Conclusions}

Previous studies of hot spring geochemistry at Yellowstone have shown that spring geochemistry, microbial ecosystems, and metabolic functions of hot spring microbial communities can change on a relatively short timescale (e.g., Ball et al., 2002, 2008, 2010; McCleskey et al., 2005). Given that the chemical composition of the source water from which the silica in each layer of Steep Cone is not known, it is difficult to state whether or not some of the elemental sequestrations in this study are more robust than others (i.e., chromium, which only appeared to be preferentially sequestered in three samples, compared to gallium, which appeared to be commonly sequestered by microbial filaments and microbial mats in all samples analyzed). It is possible the patterns documented may be attributed to a variety of factors including geochemistry and microbial community composition and function. For instance, $\mathrm{pH}$ affects a broad range of factors including microbial community composition and trace metal solubility. In addition, the variability of the presence or concentration of trace elements between samples could be due to factors including differential preservation or differing geochemistry of the hot spring at the time of deposition/silicification. Any one or any combination of these factors may be responsible for the particular concentrations for a given element. However, $\mathrm{Ga}$ appears to produce the greatest sequestration in the samples analyzed, followed by $\mathrm{Fe}$, then $\mathrm{Mn}$. These elements are not the only candidate trace elements which may have biosignature application potential, and future studies may provide insight into other elements not investigated in this study. In Steep Cone, XRD analyses suggest that no substantial diagenetic alteration to the silica has occurred throughout the exposed strata, so any major loss or change in trace element sequestration trends/concentrations is not likely to be attributed to this process. Regardless, the mechanisms- 
presumably biotic and abiotic-that lead to the apparent elemental sequestrations we observed require further study. Future studies aimed at specific microbial communities may constrain trace element sequestrations and associations to metabolic pathways or geochemical settings, and analyses of more diagenetically altered samples are necessary to characterize if this trace element sequestration trend persists in more diagenetically mature samples. Such studies could provide valuable biosignature applications if successful.

\section{Acknowledgments}

We wish to thank Annie Carlson, Christie Hendrix, Erik Oberg, and the entire staff of the Yellowstone Research Permit Office for facilitating the permitting process to perform research in Yellowstone National Park. We also thank Dr. Melodie Fickenscher for FEI Scios Dual Beam SEM/FIB setup and usage, Jeffrey Hannon for operating and assisting with SEM and XRD analyses and data interpretation, Dr. Joshua Gross for cryosection usage, and Annie Gangidine for fieldwork photography and assistance with sample collection. We also thank Steve Ruff and one anonymous reviewer for helpful comments.

\section{Funding}

The Ohio Space Grant Consortium, Geological Society of America, Paleontological Society, Sigma Xi, the University of Cincinnati Graduate Student Governance Association, and the University of Minnesota provided funding for travel and sample analyses. The American Philosophical Society, NASA Astrobiology Institute, and the University of Cincinnati provided funding for sample collection and field work in Yellowstone National Park.

\section{Author Disclosure Statement}

No competing financial interests exist.

\section{Author Contributions}

A.G. collected data, calculated SIMS data, assembled figures, and wrote the manuscript and supplementary materials. J.R.H. assisted in project design, field work planning, SIMS analyses, interpreting geochemical implications, and editing the manuscript. D.F. provided access to the SIMS and assisted in analyses, interpretation of data, and editing of the manuscript. C.J. ran all SIMS acquisitions for samples and standards, developed a quantification method for calculating trace element concentrations, wrote the specific methods regarding the $\mathrm{Ca}-$ meca IMS 7f-GEO SIMS, and edited the manuscript. T.L.H. assisted in field work planning, in interpreting the microbiology/microbial metabolisms, and edited the manuscript. A.D.C. assisted in project design and development, fieldwork, sample and data interpretations, and in writing the manuscript.

\section{Data and Materials Availability}

Yellowstone National Park samples were collected and analyzed in accordance with Yellowstone National Park Research Permit \#YELL-2017-SCI-7020 held by J.R.H. and T.L.H. Samples may not be obtained/analyzed by any individual outside of this permit unless a material transfer agreement has been established with J.R.H. and T.L.H. and the Yellowstone Permit Office. Data featured in this study are available from the corresponding author upon reasonable request.

\section{References}

Abramov, O. and Kring, D.A. (2005) Impact-induced hydrothermal activity on early Mars. J Geophys Res Planets 110 , doi:10.1029/2005JE002453.

Arvidson, R.E., Bell, J.F., III, Bellutta, P., Cabrol, N.A., Catalano, J.G., Cohen, J., Crumpler, L.S., Des Marais, D.J., Estlin, T.A., Farrand, W.H., and Gellert, R. (2010) Spirit Mars Rover mission: overview and selected results from the northern Home Plate Winter Haven to the side of Scamander Crater. J Geophys Res Planets 115, doi:10.1029/2010JE003633.

Ball, J.W., McCleskey, R.B., Nordstrom, D.K., Holloway, J.M., Verplanck, P.L., and Sturtevant, S.A. (2002) WaterChemistry Data for Selected Springs, Geysers, and Streams in Yellowstone National Park, Wyoming, 1999-2000, Open-File Report 2002-382, US Geological Survey, Reston, VA.

Ball, J.W., McCleskey, R.B., Nordstrom, D.K., and Holloway, J.M. (2008) Water-Chemistry Data for Selected Springs, Geysers, and Streams in Yellowstone National Park, Wyoming, 2003-2005, Open-File Report 2006-1339, US Geological Survey, Reston, VA.

Ball, J.W., McCleskey, R.B., and Nordstrom, D.K. (2010) WaterChemistry Data for Selected Springs, Geysers, and Streams in Yellowstone National Park, Wyoming, 2006-2008, Open-File Report 2010-1192, US Geological Survey, Reston, VA.

Bhowmick, D.C., Bal, B., Chatterjee, N.S., Ghosh, A.N., and Pal, S. (2009) A low-GC Gram-positive Thermoanaerobacterlike bacterium isolated from an Indian hot spring contains $\mathrm{Cr}$ (VI) reduction activity both in the membrane and cytoplasm. J Appl Microbiol 106:2006-2016.

Cady, S. and Farmer, J. (1996) Fossilization processes in siliceous thermal springs: trends in preservation along thermal gradients. Ciba Found Symp 202:150-173.

Cheung, K.H. and Gu, J.D. (2007) Mechanism of hexavalent chromium detoxification by microorganisms and bioremediation application potential: a review. Int Biodeterior Biodegradation 59:8-15.

Des Marais, D.J. (2010) Exploring Mars for evidence of habitable environments and life. Proc Am Philos Soc 154:402-421.

Fournier, R.O. (1989) Geochemistry and dynamics of the Yellowstone National Park hydrothermal system. Annu Rev Earth Planet Sci 17:13-53.

Handley, K.M., Turner, S.J., Campbell, K.A. and Mountain, B.W. (2008) Silicifying biofilm exopolymers on a hot-spring microstromatolite: templating nanometer-thick laminae. Astrobiology 8:747-770.

Havig, J.R. (2009) Geochemistry of Hydrothermal Biofilms: Composition of Biofilms in a Siliceous Sinter-Depositing Hot Spring, doctoral dissertation, Arizona State University, Tempe, AZ.

Havig, J.R. and Hamilton, T.L. (2019) Hypolithic photosynthesis in hydrothermal areas and implications for cryptic oxygen oases on Archean continental surfaces. Front Earth Sci Biogeoscience doi:10.3389/feart.2019.00015.

Havig, J.R., Meyer-Dombard, D.R., Raymond, J., and Shock, E.L. (2011) Merging isotopes and metagenomics: coupling biofilm $\mathrm{C}$ and $\mathrm{N}$ isotopes and metagenomics in a siliceous sinter-depositing hot spring. J Geophys Res Biogeosciences 116, doi:10.1029/2010JG001415.

Havig, J.R., McCormick, M.L., Hamilton, T.L. and Kump, L.R. (2015) The behavior of biologically important trace elements across the oxic/euxinic transition of meromictic Fayetteville Green Lake, New York, USA. Geochim Cosmochim Acta 165:389-406.

Hurwitz, S. and Lowenstern, J.B. (2014) Dynamics of the Yellowstone hydrothermal system. Rev Geophys 52:375-411. 
Johnson, D.B. (2006) Biohydrometallurgy and the environment: intimate and important interplay. Hydrometallurgy 83:153-166.

Kaasalainen, H., Stefánsson, A., Giroud, N., and Arnórsson, S. (2015) The geochemistry of trace elements in geothermal fluids, Iceland. Appl Geochem 62:207-223.

Konhauser, K.O., Jones, B., Reysenbach, A.L., and Renaut, R.W. (2003) Hot spring sinters: keys to understanding Earth's earliest life forms. Can J Earth Sci 40:1713-1724.

Konhauser, K.O., Kappler, A., and Roden, E.E. (2011) Iron in microbial metabolisms. Elements 7:89-93.

Kuroda, K. (1940) The occurrence of gallium in the hot springs of Japan. Bull Chem Soc Jpn 15:234-236.

Losi, M.E., Amrhein, C., and Frankenberger, W.T. (1994) Environmental biochemistry of chromium. Rev Environ Contam Toxicol 136:91-121.

Lynne, B.Y., Campbell, K.A., Moore, J.N., and Browne, P.R.L. (2005) Diagenesis of 1900-year-old siliceous sinter (opal-A to quartz) at Opal Mound, Roosevelt Hot Springs, Utah, USA. Sedimentary Geology 179:249-278.

McCleskey, R.B., Ball, J.W., Nordstrom, D.K., Holloway, J.M., and Taylor, H.E. (2005) Water-Chemistry Data for Selected Springs, Geysers, and Streams in Yellowstone National Park Wyoming, 2001-2002, Open-File Report 2004-1316, US Geological Survey, Reston, VA.

Muscente, A.D., Czaja, A.D., Tuggle, J., Winkler, C., and Xiao, S. (2018) Manganese oxides resembling microbial fabrics and their implications for recognizing inorganically preserved microfossils. Astrobiology 18:249-258.

Nordstrom, D.K., McCleskey, R.B., and Ball, J.W. (2009) Sulfur geochemistry of hydrothermal waters in Yellowstone National Park: IV Acid-sulfate waters. Appl Geochem 24: 191-207.

Osinski, G.R., Tornabene, L.L., Banerjee, N.R., Cockell, C.S., Flemming, R., Izawa, M.R., McCutcheon, J., Parnell, J., Preston, L.J., Pickersgill, A.E., and Pontefract, A. (2013) Impact-generated hydrothermal systems on Earth and Mars. Icarus 224:347-363.

Pierce, K.L. (2003) Pleistocene glaciations of the Rocky Mountains. Developments in Quaternary Sciences 1:63-76.

Pirajno, F. (2009) Hydrothermal processes associated with meteorite impacts. In Hydrothermal Processes and Mineral Systems, Springer, Dordrecht, the Netherlands, pp 1097-1130.

Rice, M.S., Bell, J.F., III, Cloutis, E.A., Wang, A., Ruff, S.W., Craig, M.A., Bailey, D.T., Johnson, J.R., de Souza, P.A., Jr., and Farrand, W.H. (2010) Silica-rich deposits and hydrated minerals at Gusev Crater, Mars: vis-NIR spectral characterization and regional mapping. Icarus 205:375-395.

Ruff, S.W. and Farmer, J.D. (2016) Silica deposits on Mars with features resembling hot spring biosignatures at El Tatio in Chile. Nat Commun 7, doi:10.1038/ncomms13554.

Rye, R.O., \& Truesdell, A.H. (1993) The Question of Recharge to the Geysers and Hot Springs of Yellowstone National Park, Open-File Report 93-384, US Geological Survey, Reston, VA.

Schopf, J.W., Kudryavtsev, A.B., Czaja, A.D., and Tripathi, A.B. (2007) Evidence of Archean life: stromatolites and microfossils. Precambrian Res 158:141-155.

Schuler, C.G., Havig, J.R., and Hamilton, T.L. (2017) Hot spring microbial community composition, morphology, and carbon fixation: implications for interpreting the ancient rock record. Front Earth Sci 5, doi:10.3389/feart.2017.00097.

Schwenzer, S.P., Abramov, O., Allen, C.C., Bridges, J.C., Clifford, S.M., Filiberto, J., Kring, D.A., Lasue, J., McGovern, P.J., Newsom, H.E., and Treiman, A.H. (2012) Gale
Crater: formation and post-impact hydrous environments. Planet Space Sci 70:84-95.

Shock, E.L., Holland, M., Amend, J.P., Osburn, G.R., and Fischer, T.P. (2010) Quantifying inorganic sources of geochemical energy in hydrothermal ecosystems, Yellowstone National Park, USA. Geochim Cosmochim Acta 74:4005-4043.

Skok, J.R., Mustard, J.F., Ehlmann, B.L., Milliken, R.E., and Murchie, S.L. (2010) Silica deposits in the Nili Patera caldera on the Syrtis Major volcanic complex on Mars. Nat Geosci 3: 838-841.

Smith, I.J., Lynne, B.Y., Jaworowski, C., Qasim, I., Heasler, H., and Foley, D. (2018) The formation of geyser eggs at Old Faithful Geyser, Yellowstone National Park, USA. Geothermics 75:105-121.

Smythe, W.F., McAllister, S.M., Hager, K.W., Hager, K.R., Tebo, B.M., and Moyer, C.L. (2016) Silica biomineralization of calothrix-dominated biofacies from Queen's Laundry hotspring, Yellowstone National Park, USA. Front Environ Sci 4, doi:10.3389/fenvs.2016.00040.

Spear, J.R., Walker, J.J., McCollom, T.M., and Pace, N.R. (2005) Hydrogen and bioenergetics in the Yellowstone geothermal ecosystem. Proc Natl Acad Sci USA 102:2555-2560.

Squyres, S.W., Arvidson, R.E., Ruff, S., Gellert, R., Morris, R.V., Ming, D.W., Crumpler, L., Farmer, J.D., Des Marais, D.J., Yen, A., and McLennan, S.M. (2008) Detection of silica-rich deposits on Mars. Science 320:1063-1067.

Thorne, M. (2012) How Does Nutrient Limitation Affect Expression of Assimilatory Genes for a Photosynthetic Microbial Mat Community in Yellowstone National Park? master's thesis, Arizona State University, Tempe, AZ.

Walter, M.R., McLoughlin, S., Drinnan, A.N., and Farmer, J.D. (1998) Palaeontology of Devonian thermal spring deposits, Drummond Basin, Australia. Alcheringa 22:285-314.

White, D.E., Muffler, L.J.P., and Truesdell, A.H. (1971) Vapordominated hydrothermal systems compared with hot-water systems. Econ Geol 66:75-97.

Williams, L.A. and Crerar, D.A. (1985) Silica diagenesis; II, general mechanisms. Journal of Sedimentary Research 55:312-321.

Wray, J.J. (2013) Gale Crater: the Mars Science Laboratory/ Curiosity rover landing site. Int J Astrobiol 12:25-38.

Address correspondence to: Andrew Gangidine Department of Geology 500 Geology/Physics Building University of Cincinnati Cincinnati, OH 45221-0013

E-mail: gangidaj@mail.uc.edu

Submitted 3 December 2018

Accepted 24 September 2019 Associate Editor: Christopher McKay

\section{Abbreviations Used}

$\mathrm{EPS}=$ extracellular polymeric substance $\mathrm{MRP}=$ mass resolving power

ROIs $=$ regions of interest

$\mathrm{SEM}=$ scanning electron microscopy

SIMS $=$ secondary ion mass spectrometry

$\mathrm{XRD}=\mathrm{X}$-ray diffraction 